\title{
The Urban and Architectural Characteristics of Voyvoda Street from Past to Present
}

\author{
Serengül Seçmen ${ }^{\circledR}$, Elif Süyük Makaklı 2 ๑ \\ 1 Assist. Prof. Dr., Faculty of Architecture and Design, Bahçeşehir University, Istanbul, Turkey. Email: \\ serengul.secmen@arc.bau.edu.tr \\ ${ }^{2}$ Assoc. Prof. Dr., Faculty of Architecture and Design, Işsk University, Istanbul, Turkey. Email: elif.suyuk@ isikun.edu.tr
}

\begin{abstract} Purpose

Voyvoda Street in Galata district of Istanbul originated centuries ago at the inner walls of the medieval city and was one of the most significant of its era, which has preserved its unique character and urban identity. In the nineteenth century, it became an important financial axis for the city. This study aims to understand the factors which determined the axial character of Voyvoda Street and its urban identity. The street, which is under the influence of new dynamics is examined in relation to spatial and functional transformation.

\section{Design/Methodology/Approach}

The analysis was developed by two essential components: the street and the buildings that define the character of the street by its architectural components, and their functional transformation since the nineteenth century. The axial character of the street has been evaluated due to selected criteria. The data is based on literature review, the survey of historical maps, visual materials such as photographs and gravure prints, and on-site observations.

\section{Findings}

The street has been shaped and transformed by social, political, and economic developments, external and internal migrations, the influence of modernist architectural movements, urban reforms, Western innovations in transportation, and technical developments. Voyvoda Street's strong character as an axis is determined by its historical buildings, which are attached to each other continuously that form a wall defining the boundaries of the street. It is one of the essential pedestrian connections and functions as a path. Since most of the buildings lost their original functions, following the re-use for various needs, the service and cultural industries have become dominant. Although the historical characters of some buildings have been changed by new additions, the original silhouette of the nineteenth century is still dominant.

\section{Research Limitations/Implications}

Visual materials and resources of some buildings were available in detail, while for some of them, the materials were limited.

\section{Originality/Value}

The previous studies concentrated on urban, and architectural aspects of Galata district as a whole, whereas this study focused on the urban identity of Voyvoda Street. The street and the historical buildings that define the axial character and the image of the street by its architectural components, and their functional transformation have been analyzed.
\end{abstract}




\section{INTRODUCTION}

The urban and architectural characteristics of cities are shaped by various factors at different periods in history. Social and economic changes have always been constituted the spatial formation of the historical urban areas. It is a challenge for a historical city to respond to the changing needs of urban life, and especially to maintain its identity as an accumulation of different cultures and experiences. As the buildings maintain their physical existence, the occurrence of social, economic, and political issues leads to replacing their original functions with the new ones and may lead to change in their architectural character as well.

The spatial and functional changes become an important determinant for the transformation of urban spaces surrounding them and the adaptation of new functions impact directly the identity of urban space. As NorbergSchulz (1980, pp 18) has commented; 'A place which is only fitted for one particular purpose would soon become useless. To protect and conserve the genius loci means to concretize its essence in ever new historical contexts'. In that sense, consideration should be given to the conservation of the cultural, historical heritage and also to the social and economic needs of the city. In response to the needs, functional transformation provides an opportunity to make historical environments more attractive and contributes to the competitiveness of the city.

This study discusses the functional and spatial transformation of Voyvoda Street (Bankalar Avenue) in Istanbul, which is located in the historical center of Galata and has long been one of the most significant thoroughfares in its district. For ages, Voyvoda Street has preserved its unique architectural character and urban identity. According to Schulz $(1971,81)$, 'a street represents a section of life or a small universe, where the character of the larger district is presented in the condensed form'. The identity of a city, district, or street is determined by its idiosyncratic geography, history, community, socio-cultural values, and the built environment. The Voyvoda Street is an important axis in the Galata district, due to its distinctive image determined by its built heritage, significant economic and cultural role in history, considerable location, and radical modernization in the 19th century. Still, the transformation is ongoing which is based on building-based renovation for re-use.

This study aims to identify the factors which have produced and transformed the character of Voyvoda Street and to demonstrate its spatial transformation since the 19th century. The street has been mentioned in a limited sense among urban studies of Galata and studied in detail for its historical development through a book, as an outcome of an exhibition published by Ottoman Bank Museum (Eldem, 1999). Specifically, the archive of the museum has a huge number of historical documents such as images, writings, maps, and plans, which are one of the main sources for this study. The research is structured by the following questions: What are the essential architectural features of its urban character as a historical axis, and how it has transformed in time? How functions have been changed in relation to the urban context since 
The Urban and Architectural Characteristics of Voyvoda Street from Past to Present

the 19th century? Consequently, the axial character of the street and the historical buildings, which define the impressive boundaries and image of Voyvoda Street are analyzed in terms of their architectural features and functional change.

\section{LITERATURE REVIEW}

The historical character of urban space is defined as a whole including location, heritage, architectural assets (Bullen \& Love, 2011) such as the street, which is defined by the boundaries of the buildings (Scott, 2008; Plevoets \& Van Cleempoel, 2013; Powell, 1999). Many historical analyses of the built environment demonstrate that streets are the essential elements for the formal organization of the settlement form. Moughtin (2003, pp.131) defines "the street as a link between buildings, both within the street, and in the city at large" and "the street is also a path, which is two-directional". Due to Moudon (1991, pp.13) "More than any other element of the urban infrastructure, streets both record and determine the history of city form." Also, Rapoport (1987, pp.81) demonstrates the street as "the more or less narrow, linear space lined by buildings found in settlements and used for circulation and, sometimes, other activities". In addition to the formal meaning of the street, some scholars emphasize the public aspect of it. For instance, Kostof (1992, pp.114) points out "The only legitimacy of the street is as public space". According to Carmona et al. (2003, pp.111), "streets constitute the public space in its purest form that is accessible to all". Also, Smithson et all. (1967, pp.15) says "the street is not only a means of access but also an arena for social expression".

The memories of a historical city are embedded on its streets including public, cultural, and commercial buildings and urban spaces. Revitalization of historical streets has the potential to restore their unique image and identity (Mehta, 2013). These areas are essential to social interactions, which produce cultural heritage (Zukin, 2012), and also attract tourists, visitors, and commercial activities (Bandarin, 2015). Since the '90s, urban built heritage areas, which define the identity of the city or a place, are essential to urban and economic development (Bandarin and Van Oers 2012; Aspa, 2004; Ashworth \&Tunbridge, 1990; Ashworth \&Larkham, 1994; García-Hernández M, De la Calle-Vaquero M, Yubero C., 2017). The identity or character of a place has been variously termed as 'genius loci', 'place-identity', and 'sense of place' (NorbergSchulz, 1980; Relph, 1976; Lynch, 1960; Steele, 1981), and the physical environment, which is mostly characterized by the buildings enrich the local character and provide a sense of place (Lowenthal \& Binney, 1981). Relph (1976, pp.30) refers to the importance of the physical environment in his comment on the place as 'possessing intangible qualities, changing through time and, above all, having a physical, visible form'.

Gibberd (1955) asserts the street as a space where buildings are grouped to form a series of street views while Gutman (1986) defines the street as a type of intermediate urban space between buildings and other open 
spaces. Together with the building's relation to each other, the physical factors that have a strong impact in the planning process of a street are "user density, land-use mix, pedestrian-vehicular interaction, configuration and context" (Schumacher, 1986 pp.132).

All types of visual elements of the historical urban areas are one of the essential inputs of the morphological analysis for historical urban areas. According to Hosagrahar (2015), the importance of analyzing visual elements lies behind figuring out the components of urban identity. Especially, the analysis showing figure-ground or solid-void relations, the hierarchy of buildings and urban spaces, and the links connecting them are part of the identification of the physical articulation of the urban area. For the analysis of urban space in the urban scale, the aerial maps are beneficial tools to define the exact location of buildings, streets, or natural areas. Visual documentation of the street elevation is also necessary for the analysis. Visual representation of the street elevations including visual integrity is important for any kind of intervention, restoration, or re-functioning of the buildings (Hosagrahar, 2015).

Classification of buildings and urban spaces based on their spatial aspects such as formal language, visual elements, or typology is also an important tool for the analysis. For instance, the classification of buildings defining a street elevation may be based on the height of the buildings, their location on the street, architectural features, the function of the buildings, or the geometry of the facade, facade materials, or roof form of each building (Hosagrahar, 2015). Moughtin (2003) makes a suggestion more based on the urban design about analyzing the form of the street regarding the qualities such as straight or curved, long or short, wide or narrow, enclosed or open, formal or informal. Also, the street can be analyzed in terms of its scale, proportion, or connections to other streets and squares.

Galata was surrounded by the medieval city walls, which is seen in the gravures of the 15 th century. The 1905 Goad map shows that the density of the built environment increased and Voyvoda Street is seen as an important axis (Çelik, 1998). In the 19th century, many large commercial and public buildings were built that define the urban identity of the Street (Akın, 1998). Although Voyvoda Street is not a main Street today, it forms the horizontal axis of the region (Eroğlu, 1992; Çelik, 1998). In this study, the factors which have produced and transformed the character of Voyvoda Street since the 19th century is analyzed.

\section{RESEARCH METHODOLOGY}

The analysis is based on defining the changing character of the street by its architectural features of historical buildings and axial analysis regarding specific urban space criteria, and functional change since the 19th century (Figure 1). According to Larkham and Jones (1993), to evaluate the character of the urban space townscape analysis should be done that studies the essential elements such as buildings, open spaces, streets, and site layouts. Also, the massing and height of buildings and the 
The Urban and Architectural Characteristics of Voyvoda Street from Past to Present

relationship between existing structures and open spaces should be given importance among these analyses.

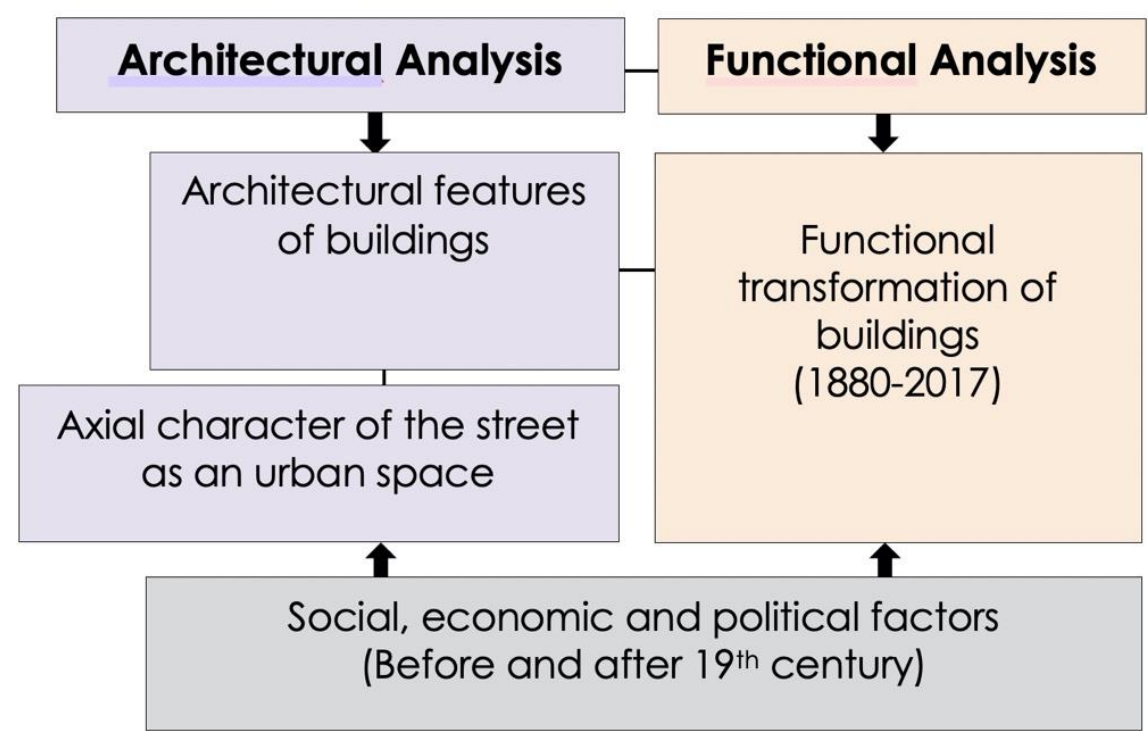

Figure 1. Analysis for spatial and functional change

Fifteen buildings have been selected as they reflect Voyvoda Street's urban identity. The main selection criteria are the architectural style such as their facades and construction systems, and the construction period of the buildings no later than 1880-1920. In this study, the spatial and functional analyses are conducted for four significant periods (1880$1920 ; 1990 ; 2010$; and 2017). The axial analysis is based on the urban space criteria compiled from the works of Schulz (1971) and Lynch (1960), which are;

- the images and activities at the starting and ending points of the connections and movement,

- the relative width of the street,

- the block structures,

- the dimensions and lengths of the facades,

- horizontal and vertical components,

- symbolic direction with its image and historical function,

- a place for urban activities (destinations along the axis).

The discussion considers the transformation in relation to urban issues, especially about how social, economic, and political factors of the nineteenth, twentieth, and twenty-first centuries have had significant impacts on Voyvoda Street. The data used in this study is based on a literature review, the survey of historical maps (Pervititch, 1905; Goad, 1905; Stolpe, 1863; Cavand, 1872-74; Moltke, 1836; Kauffer, 1786; D'ostoya, 1860), visual materials (such as photographs and gravure prints) as well as on-site observations. 


\section{THE SPATIAL DEVELOPMENT OF VOYVODA AND ITS URBAN CONTEXT IN HISTORY}

Istanbul, a city with varied, dynamic, and global relations, has been a heterogeneous cultural and physical phenomenon for 1,500 years. It is constantly influenced by changing life conditions, cultural variations, hybrid spatial formations, dynamic urban practices, diverse social expectations, and continuously evolving identity (Batur, 1996; Kuban, 1998; Bilgin, 2010; Akpinar, 2011; Akin, 2011). Istanbul, as a twenty-first century World city, is a global metropolitan with complex urban characteristics and it is subject to ongoing change with large-scale projects (Dokmeci, Altunbas, \&Yazgi, 2007; Özbay, C., \& Candan, B. A., 2014; Güvenç, M., et al., 2012).

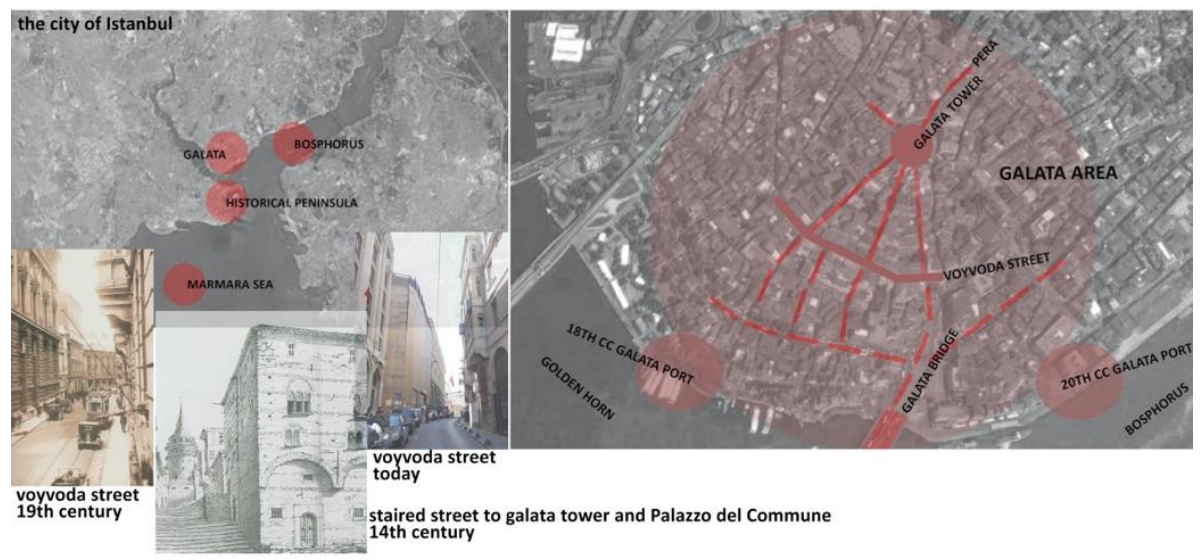

The urban structure and the image of the city have been governed by its dynamic topography, distinctive natural environment, and geographical position between the Marmara Sea, the natural harbor of the Golden Horn, and the international waterway of the Bosphorus. The first settlement area was the peninsula (known as the Historical Peninsula, and the city's administrative center), which is located between The Marmara Sea and the Golden Horn, declared as World Heritage Site by UNESCO in 1985. Kuban (1998) defined the eighteenth-century Istanbul as a Western mercantilist city whose character was the product of its specific West-East culture. In the nineteenth century, Istanbul consisted of three main settlements geographically separated from each other by water: Istanbul (historic peninsula), Galata, and Uskudar. Galata, with its harbor to the north of Istanbul and its location across the Historical Peninsula, is where trade relations with the West were established and operated (Figure 2).
Figure 2. Voyvoda Street and Galata district context 
Figure 3. Historical Galata settlement in the fifteenth century (Matrukçu Nasuh, Gravure, 15 th century)
The Urban and Architectural Characteristics of Voyvoda Street from Past to Present

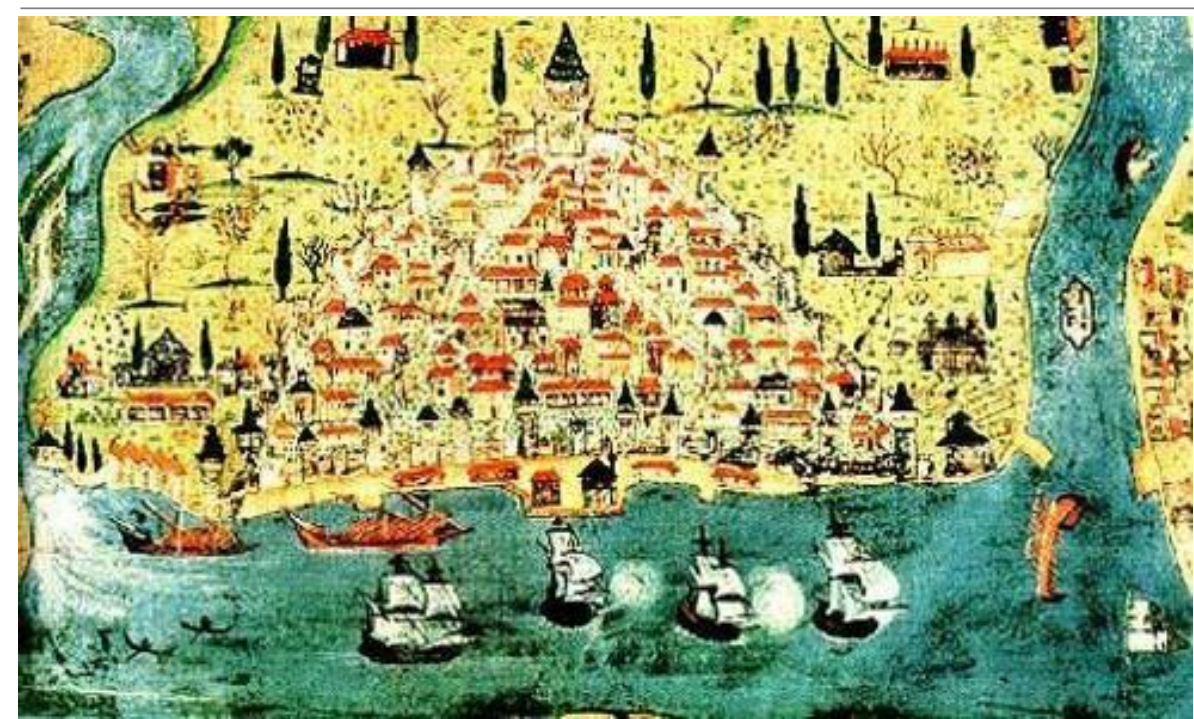

The history of the Galata region dates back to ancient times. Before the fall of Constantinople in 1453 (İstanbul), Galata was a Genoese colony and had the characteristics of a walled medieval city (Eyice, 1996; Akin, 1998; Celik, 1998; Batur, 2001) (Figure 3). Unlike the Historical Peninsula, which was established as a planned Roman city, Galata was developed in an organic manner (Batur, 2001). In the fifteenth century, Italians, Jews, Armenians, and Turks were living in Galata, each in their own neighborhoods separated by walls. The social and cultural context was the main determinant for the spatial layout of Galata since the traces of these walls were the prospective streets of the nineteenth-century Galata (Eyice, 1996; Akin, 1998; Celik, 1998; Batur, 2001).

Throughout its history, Galata has always been an important port settlement. Like the other port cities, different ethnic and religious groups settled in Galata. In addition to various religious structures (such as churches and synagogues), the first municipality, theatres, embassies, hotels, a stock market, banks, translation bureaus, trade centers, and warehouses were built there. Typical for an important port city, Galata was distinguished until the end of the nineteenth century by its colorful urban life, with its many restaurants, cafes, casinos, taverns, and passages (Akin, 1998; Celik, 1998; Batur, 2001).

As a matter of fact, there are cities in history established, dominantly, for trade purposes. For instance, the medieval bastide, a European form, adopted a rectangular regular street plan, which served as an economic place, with trade being a major function. Streets had equal status in the bastide, which had no central avenues or broad boulevards that were designed as working places (Hartshorn, 1992). Much like the medieval bastide, the medieval Galata had the role of being the trade center of the city but its streets didn't have the regular order like the bastide. The city had the traditional morphology of Mediterranean port cities: it pursued maritime activities, connected the city's main axis to the port, and constructed important commercial centers (Eyice, 1996; Akin, 1998; Celik, 1998; Batur, 2001). 


\section{Significant Determinants for the Development of Voyvoda Street}

The nineteenth-century is the most determinant period for the urban identity of Galata. Due to reforming policies, as well as new urban standards and ideas, Galata was the first settlement in the Ottoman Empire to experience a process of modernization. The demolition of the medieval walls and the construction of new streets in their place in the 1860s are considered as important developments. These streets, which formed a network that expanded accessibility, were constructed according to European models rather than to the traditional pattern of Ottoman cities (Figure 4). As a business and commercial center of the city, which has improved physical accessibility significantly benefited Voyvoda (Eyice, 1996; Akin, 1998; Celik, 1998; Batur, 2001).

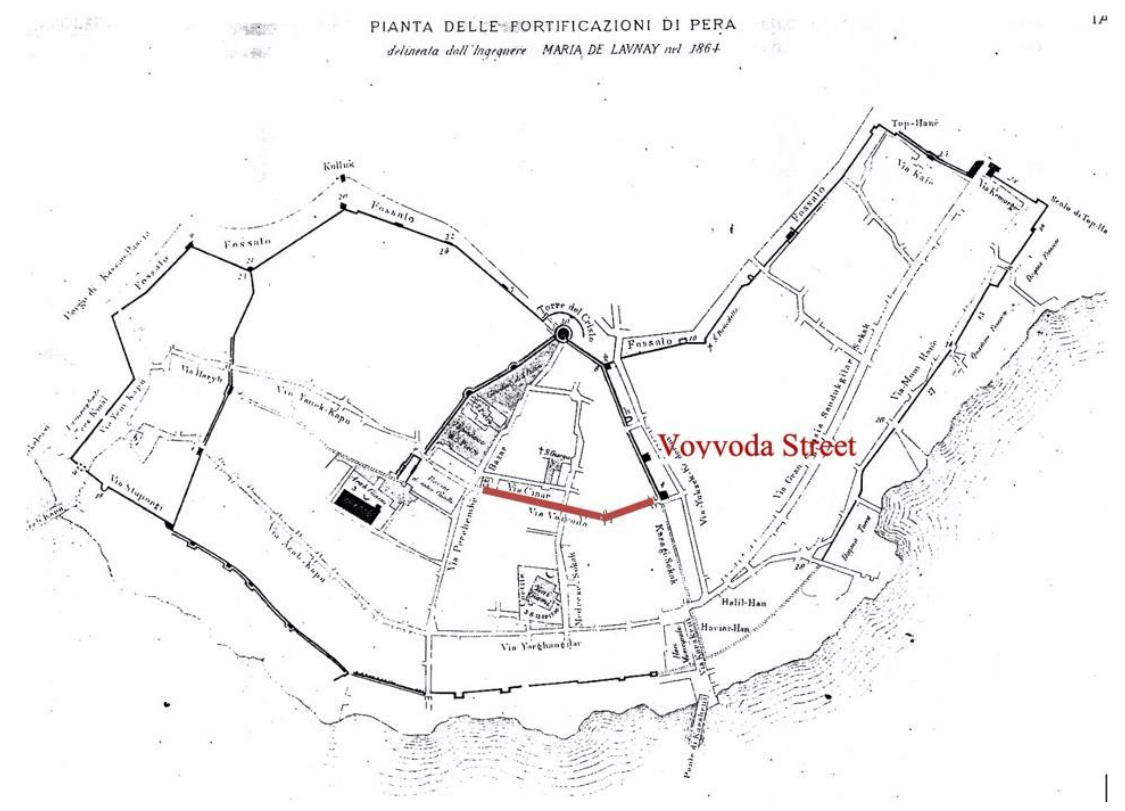

In general, practices introduced by administrations frequently bring about changes in the architecture of that particular country and the appearance of its cities. The change may be displayed in architectural forms, stylistic features, construction techniques, materials employed, or even in large urban layouts (Can, 1999). During the reformist movement in 1839 due to the urban policies, traditional wooden architecture was replaced with masonry structural development, which had a huge impact on the Galata and the city's image (Gençer, C.I.., Çokuğraş, I, 2016). At the beginning of the twentieth century, the urban image of Galata was characterized by high-rise masonry buildings with bank and inns' functions, which were located particularly on Voyvoda Street and Kemeralt street and their surrounding areas, and by dense housing units higher on the hills (Akin, 1998). According to Ortaylı (2016), the nineteenth-century Galata represented the European way of life in the Eastern Mediterranean with its environment of masonry buildings, multilingual and multicultural population, and varied entertainment events (Ortayli, 2016). In Galata and Pera districts, the European city
Figure 4. 1864 Launey Plan (Jean-Luc Arnaud, 2009; from'Une source pour l'histoire de l'espace urbain: l'investigation des documents iconographiques représentant les villes de l'Orientméditerranéen. Panzac. Les villesdans l'Empire ottoman: activités et sociétés', CNRS, pp.121-47, 1991. <halshs-00423964>) 
The Urban and Architectural Characteristics of Voyvoda Street from Past to Present

image created by its architecture and urban environment, with buildings inspired by Western European styles, reflecting the distinctive character of the population and the role of global financial powers in the urban space of Ottoman society (Eldem, 2000; Akin, 1998).

\section{THE ROLE OF VOYVODA STREET AS AN AXIS}

The pre-urban villages and settlements had the organic paths for movement, and as cities developed these paths evolved into formal street networks. The street as an institution is a critical subject with its architectural identity, economical activities and social aspect. According to Kostof (1992), the purpose of the streets included physical connections and social exchange. Thus, the street is both a container and has its specific content (Kostof, 1992).

The Voyvoda Street of Galata had been an important axis in history, which extended parallel to the waterfront and on which were lined administrative and government buildings. The Genoese parliament building and the market square were located there; subsequently, Ottoman local administrations were located on Voyvoda Street as well, preserving the area's significance. During the nineteenth century, a new social, economic and architectural development in Galata resulted in the construction of banks. In particular, the Ottoman Bank designed by Alexander Vallaury was constructed in 1890 with its twin monumental buildings and was considered the main attraction of the street at the time. Following the Ottoman Bank, numerous other banks, such as Banco di Roma, Deutsche Bank, and the Banque d'Athenes, took their place on the axis, to be followed later by local banks, such as the Central Bank. As a result, the road was renamed Bankalar (Banks) Street. In the final fifty years of the Ottoman Empire, Voyvoda Street hosted companies related to banking, insurance, law, architecture, mining, railways and technology, which was creating the distinguished urban identity. Most of the large commercial buildings, that were built on the axis, followed the plans and layouts of typical European structures for business, with impressive facades and interior architectural features (Akin, 1998; Celik, 1998).

The development of the transportation system had a huge impact on the development of the street. As the borders of the city expanded in the nineteenth century, so public transportation developed rapidly. Public transportation between the Historical Peninsula, Galata, and the Bosphorus villages were provided by waterways that made use of the city's waterfront character. At the end of the nineteenth century, the Historical Peninsula and Galata became connected by the Galata Bridge, which is a pedestrian and vehicular bridge that formed a strong axis affecting development (Akin, 2011). The first horse-drawn trams operated on Voyvoda Street in the second half of the nineteenth century and electric trams started to serve the area at the beginning of the twentieth century (Celik, 1998). Like other streets (Cadde-I Kebir, Tepebaşı) in the district with high population density, Voyvoda street benefited from the extension of the tram network. The stalls and 
administration center of the tram company were also located on the Street and enhancing its importance as an axis of the district (Eldem, 2000).

Another Western innovation providing transportation was a railway tunnel between Galata and Pera, the construction of which was completed in 1874 (Akin, 1998). Voyvoda Street became an important center in Galata and also in Istanbul as a whole in the second half of the nineteenth century (Eldem, 1999; Eldem, 2000). The Galata stock market, which was founded in the 1850s, was one of the most important stock exchanges in the world until the late 1920s (Altan, 2007; Alpay, 2007). The most important financial and stock exchange activities were conducted by Galata bankers, who were highly influential in the economic life of the Empire. In addition to the stock market, vibrant economic activity occurred in Street's inns, trading centers, bureaus, warehouses, and shops (Akin, 1998).

However, following the proclamation of the Republic, Ankara became the new capital, and the population of Istanbul declined in the1930s. Consequently, Galata gradually began to lose its attractiveness as a commercial center. Again, in the 1950s, the city faced a period of demographic expansion resulting from immigration, a phenomenon that has continued to the present day. Mass immigration from Eastern Turkey, as well as the migration of the non-Muslim population for political reasons, has led the Street to changes in social profile and economic activities. The Street has experienced new economic activity through the expansion of electronic retail due to the rapid growth of technology during the 1950s. In the 1990s, Levent-Maslak urban axis was developed as the Central Business District, attracting the administrative headquarters of financial companies, which were previously located on Voyvoda Street. Today, the Street still accommodates some banks, alongside some electrical supply shops (Eldem, 1999).
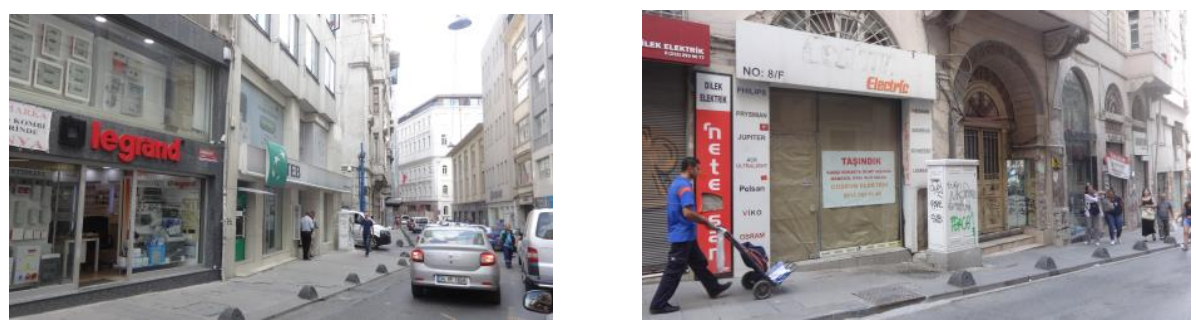

Since the beginning of 2000s, technological and electrical retail is being replaced by other services, such as accommodation, culture, and leisure services. The main reason behind this functional change is the rise of arts and culture centers in Galata and Pera. In the 2000s, museums and modern art institutions have established in the city (Hansen, 2012). Also, the redevelopment of old Galata Harbor as a Cruise Terminal has triggered the urban tourism and economy. Today, most of the electrical supply shops have already left the street and there is an ongoing process of restoration for re-use (Figure 5). Although the street is developing, the number of
Figure 5. Electrical retail, banks and abandoned buildings (Photo: Authors). 
The Urban and Architectural Characteristics of Voyvoda Street from Past to Present

abandoned buildings is not negligible. As mentioned above, sociological, economic and political factors were the main determinants of spatial and functional change for the axis. Despite the radical functional and socioeconomic change in the historical process, the axial and architectural character of the street is still defined by its historical buildings.

\section{SPATIAL AND FUNCTIONAL ANALYSIS}

\section{Spatial and Functional Analysis}

Initially, the functional transformation is demonstrated through four different periods of the 1890s, 1950s, 2010s and 2017, which were determined due to significant changes. These analyses are going to be evaluated by considering the socio-economic determinants of its period. As Harvey has noted, political and economic developments are strongly connected to spatial production (Harvey, 2008). The physical context of Voyvoda Street, which generates a unique identity, is shaped in the nineteenth century due to the diffusion of the global economy. Around the 1890s, there were various functions such as retail (daily services like bakery, pharmacy, pub), trade (mechanical companies), global financial and insurance companies, warehouses, post offices, Ottoman Bank, and even residential units. The street was more like a commercial street. Later on, with the influence of the Ottoman Bank at the beginning of the 20th century, banks and other financial functions were increased and the street gained more financial character. Around the 1950s, electrical and mechanical supply was flourished and became dominant, due to the mass migration. The end of the 20th century was the time when most of the financial companies moved to the New Business District in LeventMaslak, resulted in an increase in electrical supply retail, which has continued until the 2000s (Eldem, 1999).

Figure 6. Functional change (1880-2017), reproduced from Eldem (1999) and onsite studies.

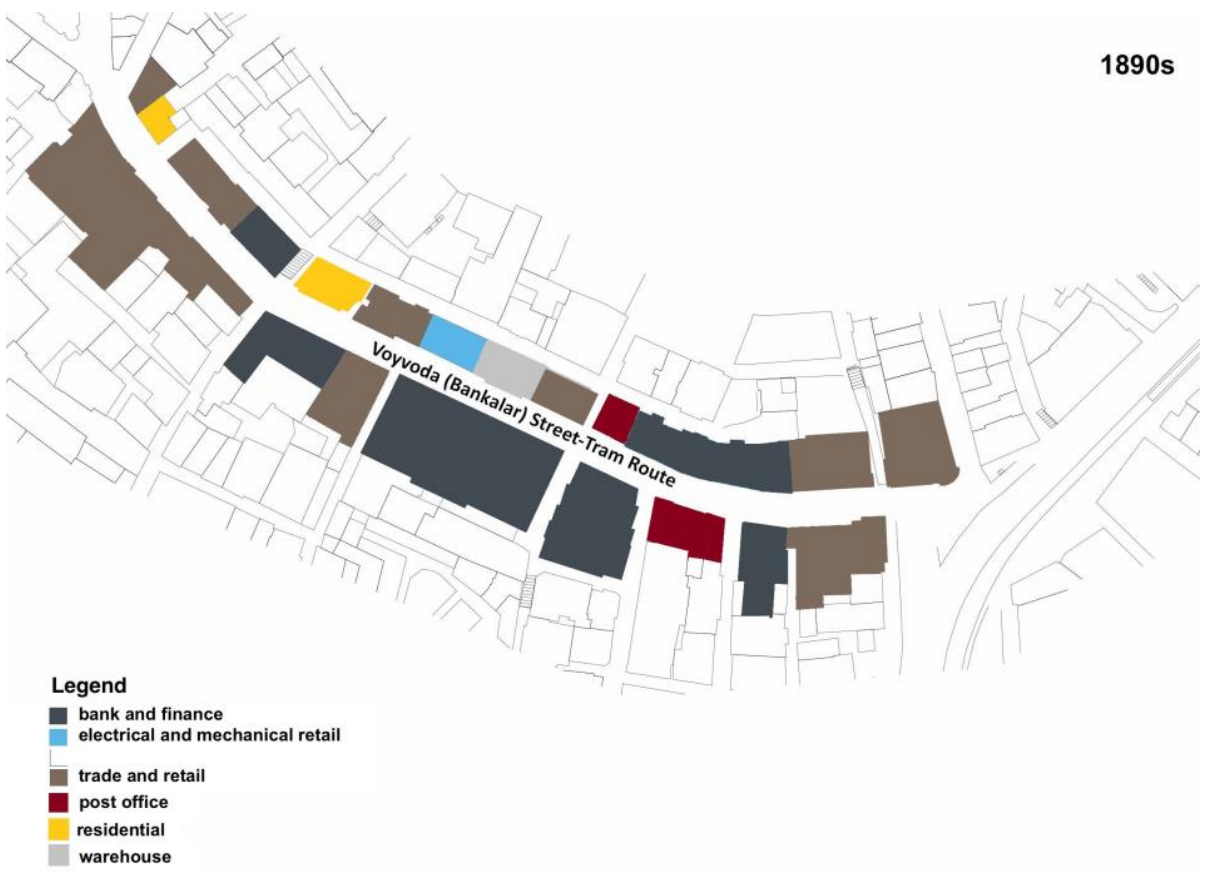




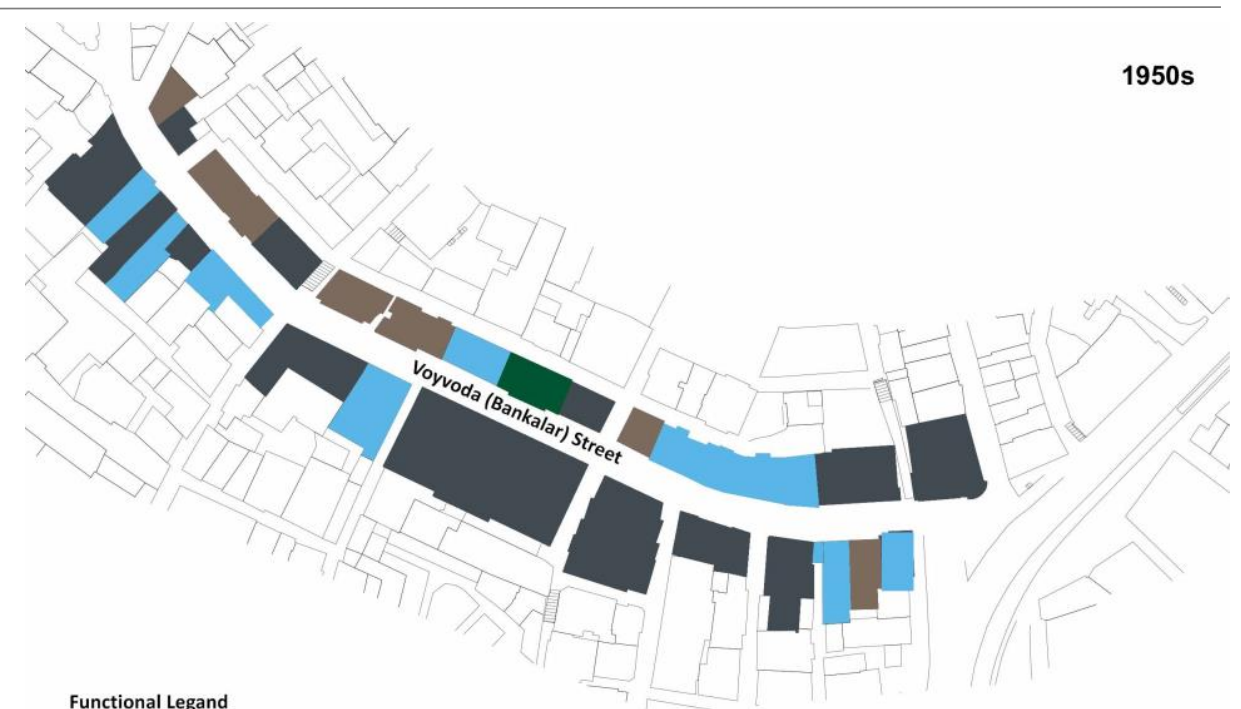

Functional Legand

bank\&finance

electrical\&mechadministratio

governmental ail
mixed-use retail

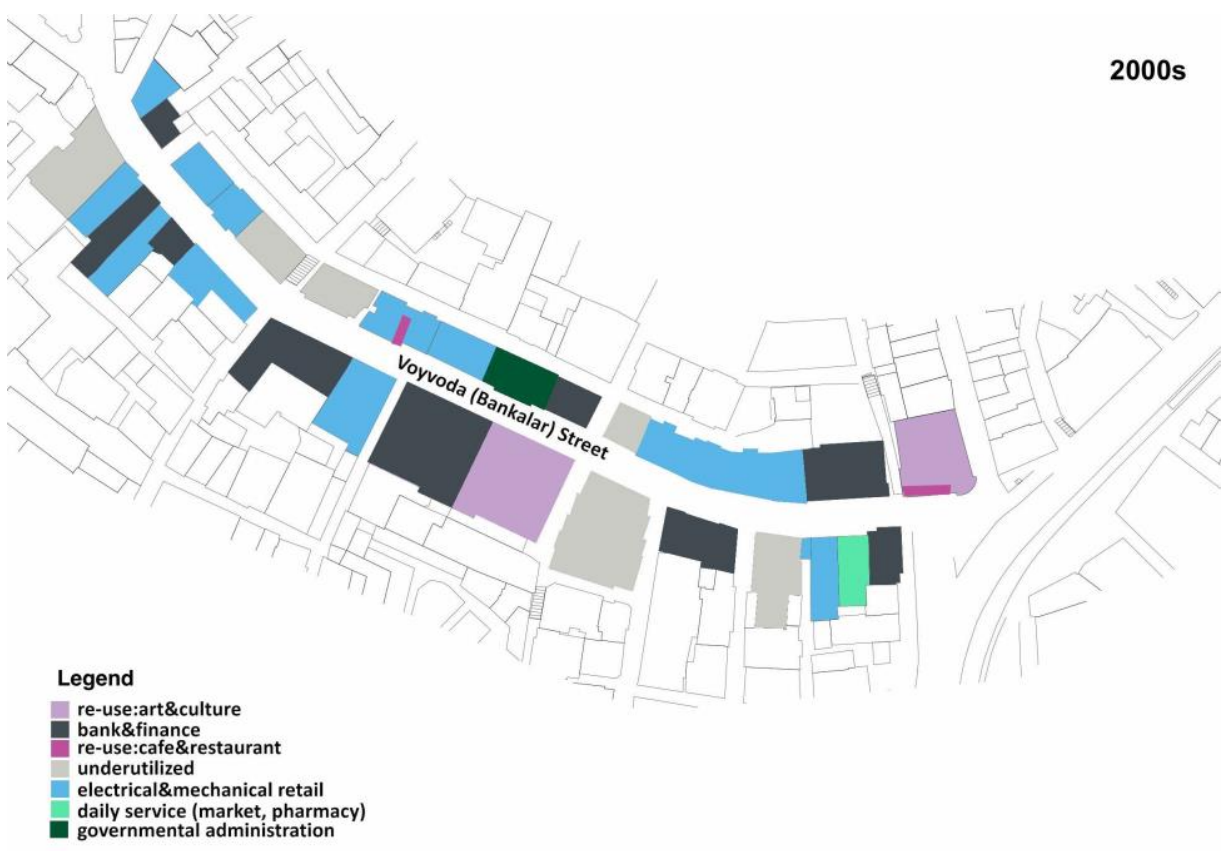

Figure 7. Functional change (1880-2017), reproduced from Eldem (1999) and onsite studies.

Figure 8. Functional change (1880-2017), reproduced from Eldem (1999) and onsite studies.
The SALT and the Ottoman Bank Museum have been established in 2011 in the former Ottoman Bank building, as a reflection of the growth in the arts, culture, and service industry in the city. Once again in history, the Ottoman Bank building came onto the ground as the dominant function, which has launched the revitalization. The functions have been diversified as daily services, cafes, and cultural institutes and still facing an ongoing re-functioning process. Today, a considerable number of underutilized buildings wait for their new functions. Electrical and mechanical supply retail has almost left. Besides, by the influence of urban tourism and the economy, specifically Galata Port development, the accommodation service is taking its place on the street. The identity 
The Urban and Architectural Characteristics of Voyvoda Street from Past to Present

of the street is going to be defined by the new functions such as arts, culture, leisure, business, accommodation, and prospective services (Figure 6, 7, 8, 9).

Figure 9. Functional change (1880-2017), reproduced from Eldem (1999) and onsite studies.
Figure 10. Views from Voyvoda Street (Photos: Authors).

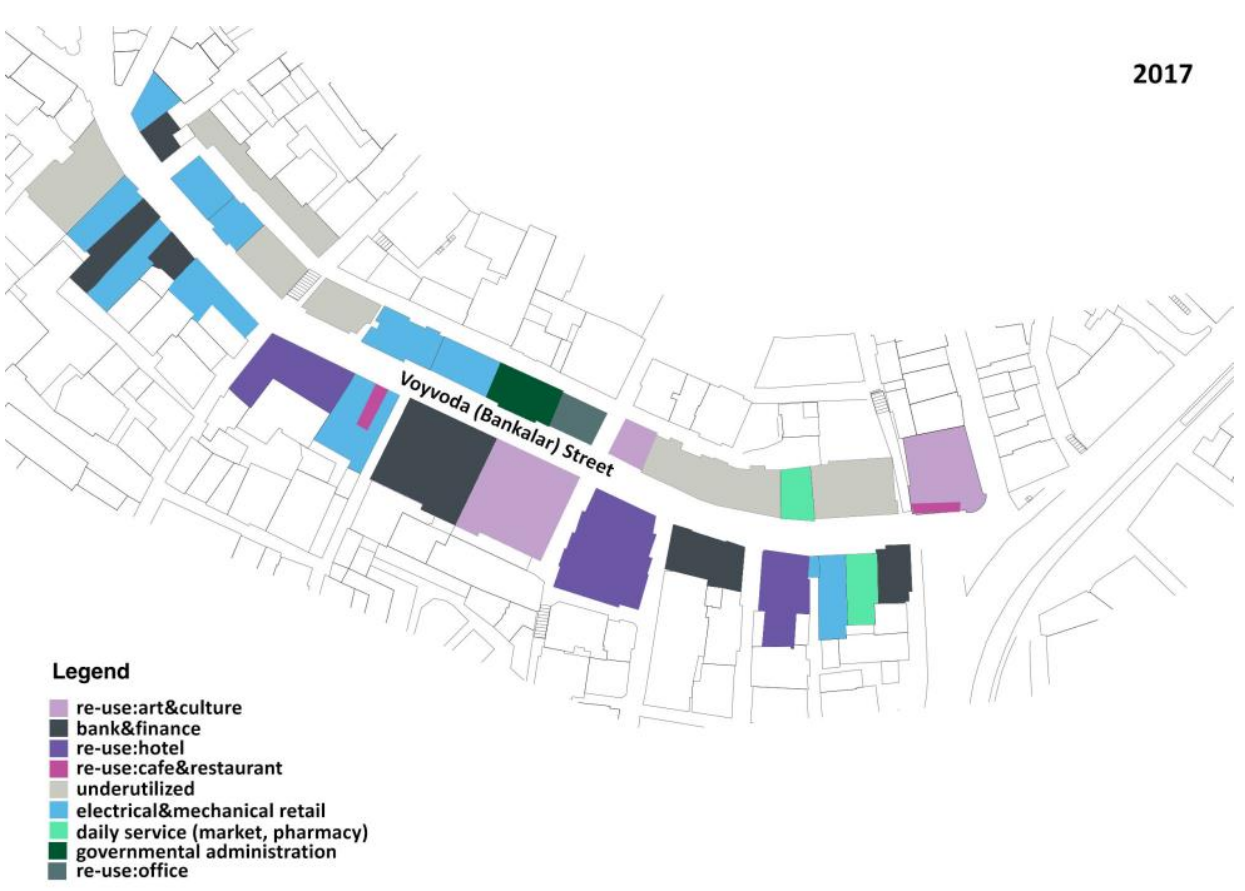

\section{The Axial Character of the Street as an Urban Space}

In contrast to the various functional alteration, the spatial change of the street is more static. The significant spatial features are the role of its axial character and place identity that depends on its physical components, which comprise the buildings connected to each other constituting a continuous urban wall parallel to the street itself. These masonry buildings reflect the powerful image of their original economic and administrative functions in the nineteenth century. Although the height of the original façade of the street has been changed, the axial character is still maintained (Figure 10).
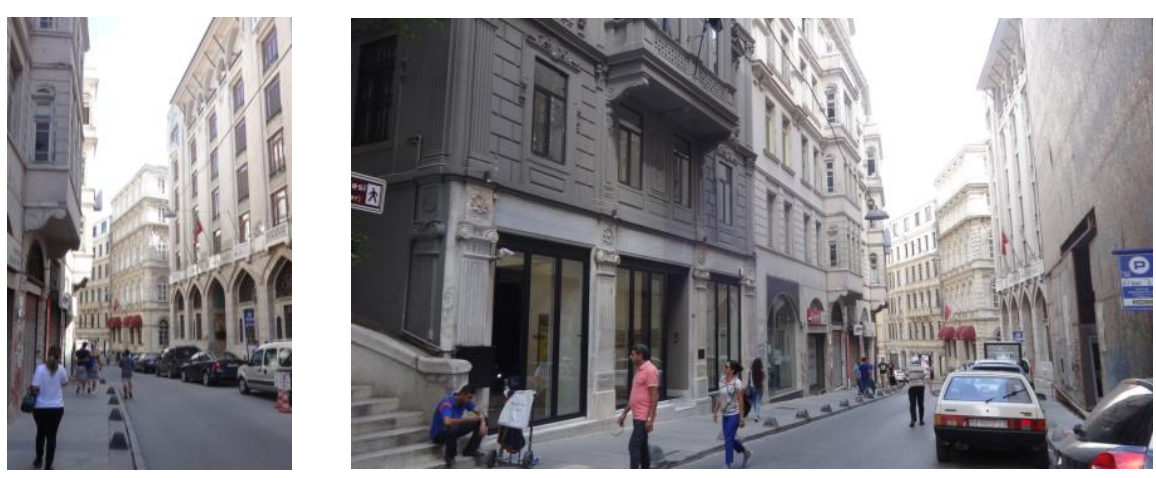

In terms of its spatial properties, Voyvoda Street functions both as a path and an axis, which makes it a unique artifact. It is an essential path for movement within the district and it represents a symbolic direction with 
its image and historical function. It has horizontal as well as vertical components, demonstrating its figural character and its role as a place for urban activities. As Schulz (1971) has suggested, the organizing axis is not intended for real movement; rather, it represents a symbolic direction that unifies several elements and often relates to a larger totality. Often, the path and axis are identical that the real path, and the more abstract axis may have horizontal and vertical components (Schulz, 1971). According to Lynch (1960), an urban axis contributes to the formation of the city image. The images and activities at the starting and ending points of the connections, the relative width of the streets, the block structures, the dimensions and lengths of facades are important in scaling people to the city. The Voyvoda urban axis provides a link between the buildings all along the street, and to the wider city. It intersects another axis, which leads to the Galata Tower, one of the most iconic symbols of the old city.

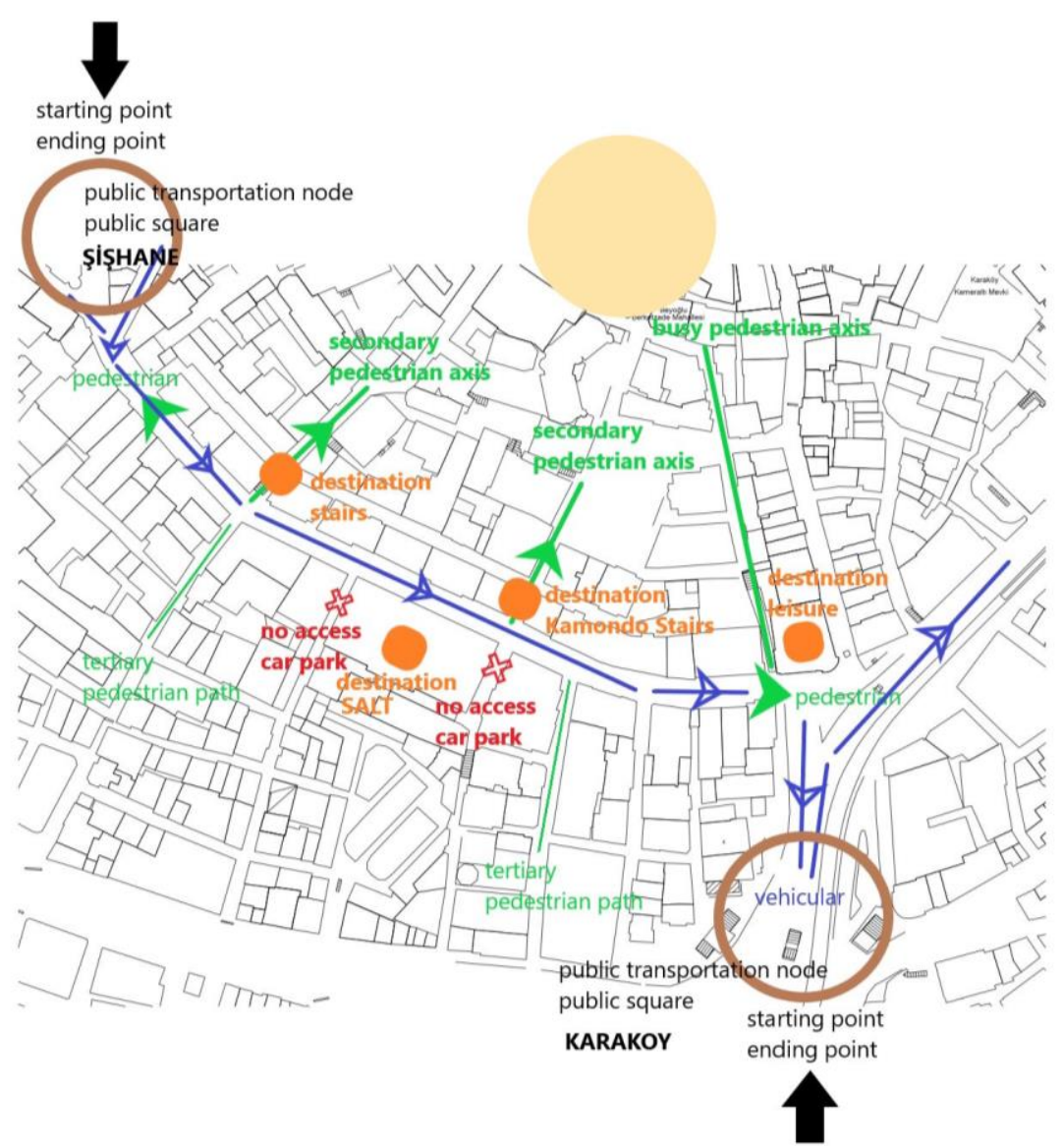

Considering the axial character of the street and architectural features of the buildings, the spatial analysis developed by these two essential components: the street and the buildings. Initially, for the analytical evaluation for the axial character of the street, eight criteria are demonstrated, which are the images and activities at the starting and ending points of the connections and movement, the relative width of the street, the block structures, the dimensions, and lengths of the facades,
Figure 11. Axial Character of Voyvoda Street (1). 
The Urban and Architectural Characteristics of Voyvoda Street from Past to Present

horizontal and vertical components, symbolic direction with its image and historical function, and a place for urban activities (destinations along the axis).

Figure 12. Axial Character of Voyvoda Street (2).

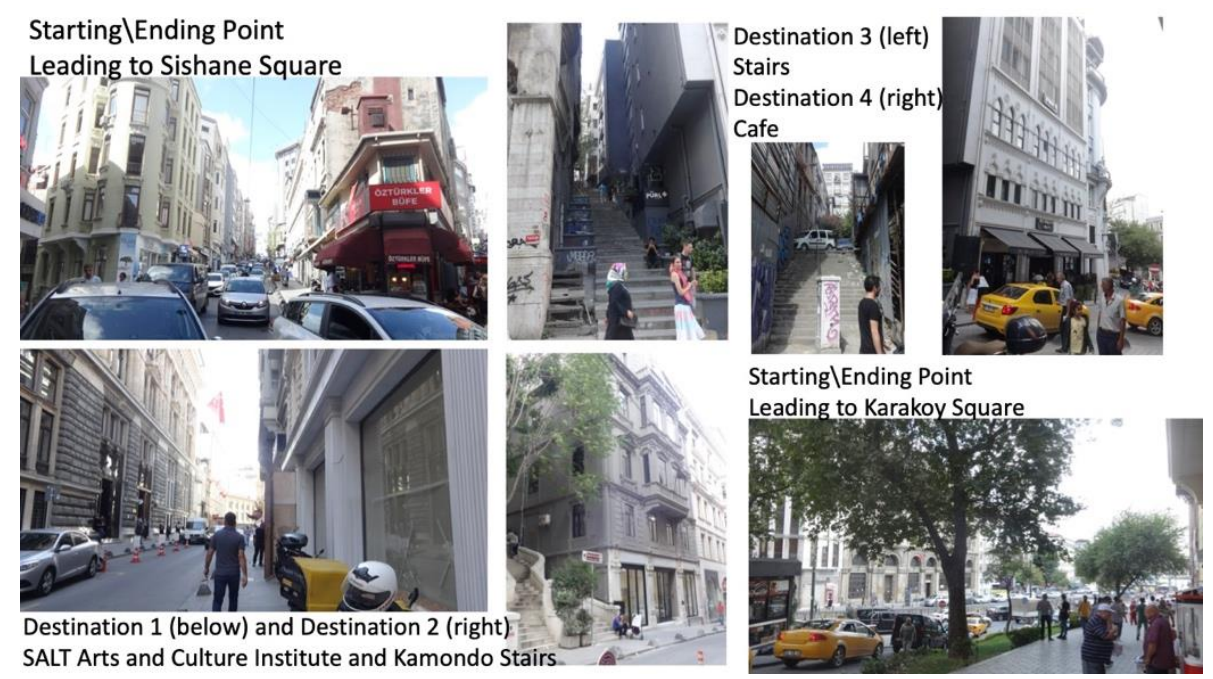

- The images and activities at the starting and ending points of the connections and movement: Voyvoda is the main connection between two busy nodes, Sishane and Karakoy, consisting of several modes of public transportation. Karakoy Square is the citywide public transportation node of the essential tramline, metro line, bus, tunnel tramline, waterborne transportation, and pedestrian movement. Sishane is not as busy as Karakoy Square in terms of pedestrian movement, but it is still one of the essential starting $\backslash$ ending points for pedestrian connection from Voyvoda to Karakoy. In this case, these two public spaces are the main stationaries providing pedestrian movement up and down along the Voyvoda. The Galata Tower is the image, as being a historical and touristic attraction, which provides the secondary pedestrian movement from Voyvoda. Other pedestrian paths don't function as an axis due to a lack of activities and no entrance to the buildings. Even, some of these narrow and dull streets function as car parking. Vehicular movement pours down only in one direction from Galata to Karakoy Square through Voyvoda, which dominates the axis during the daytime. Voyvoda has a strong relation with Galata Bridge that is one of the significant connections between Historical Peninsula and Galata (Figure 11 and Figure 12). 


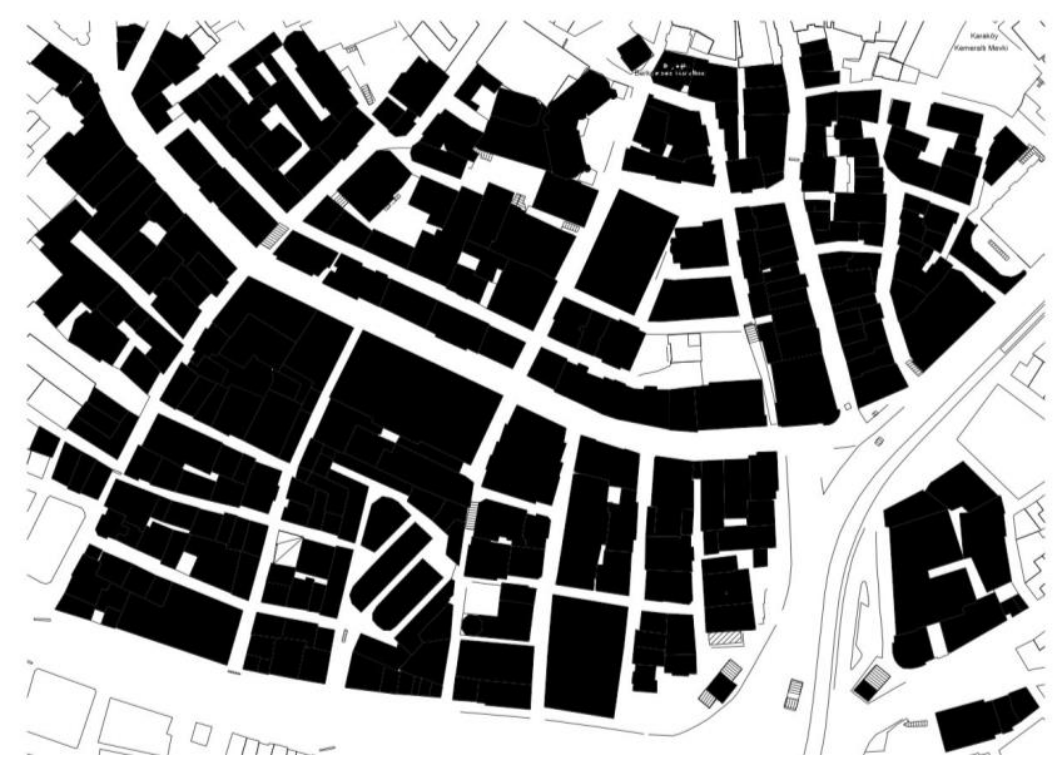

Figure 13. Figure-Ground Relation of Voyvoda Street.
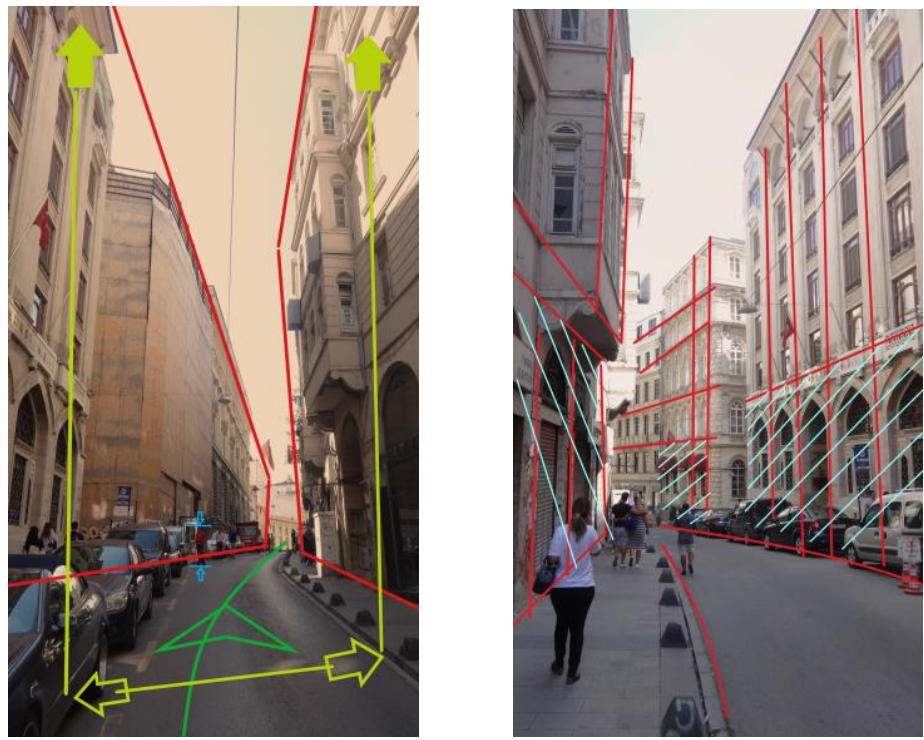

Figure 14. Axial Character of Voyvoda Street (3).

- The relative width of the street: The regular street pattern surrounding Voyvoda provides permeability and the good quality physical access from Voyvoda to Galata and Karakoy. Considering figure and ground relation, Voyvoda Street is seen as the spine of the network in terms of its central location, which intersects and connects the lateral streets. Although it is obvious that Voyvoda Street is the widest in comparison with the width of the other streets in the network, the silhouette of the Voyvoda Street cannot be perceived easily by pedestrians due to the height of the buildings. Consequently, the street is proportionally narrow due to its top-level, but still largest within the network (Figure 13 and Figure 14).

- The block structures: The figure-ground relation shows that the physical context comprises massive structural elements (Figure 13 and Figure 14). 
- The main components of this pattern are the inns and the architectural typology of European-based economic function. This is valid also for the rest of the context, where the trade and economic function was dominant before.

- The dimensions and lengths of the facades: The lengths of the façades at both sides of the street are continuous and the dimensions are perceived as if there is a sense of proportion due to their height and width. However, the sense of human scale is weak, which is related to the proportional width of the street and the height of the buildings. So, the street is perceived narrower (Figure 13 and Figure 14).

- Horizontal and vertical components: The buildings are the main components and the essential configuration of the facades are vertical and horizontal. The rectangular planes of the entrance spaces with the higher level are providing a sense of direction horizontally, which are composed of vertical elements (Figure 14).

- Symbolic direction with the image and historical function: The buildings on Voyvoda are constituting a continuous wall parallel to the street itself. These masonry buildings reflect the image of their historical economic functions of the nineteenth century in terms of symbolic direction for the axial character (Figure 14).

- A place for urban activities (destinations): The opaque façade of the buildings provides limited visual relation between the outdoor and indoor. This necessitates the destinations for various urban activities to maintain the sense of place and vitality of the street. In terms of supporting urban activities, there are three essential and attractive destinations. These are the two narrow streets-partially staired; a café directed to the view of both Voyvoda Street and Karakoy Square; and SALT the arts and culture institute. So, the destinations provide urban activities of recreation, arts and culture, education, and movement that provides a ground for socializing and strengthens the potential of the street as a public space. In addition to its arts and culture activities also on the street level the activities such as waiting, standing, watching, having a conservation occurs in front of the SALT. Three destinations are strong as second movement axis providing connections to Galata Tower Square. Additionally, one of these destinations has one of the unique historical Kamondo stairs in Istanbul constructed in the nineteenth century. It provides another essential ground for urban activities such as standing, watching, taking the photo, sitting on the steps, and meeting. Frequently, tourists, visitors and even local people take photo of themselves with the stairs background. In this case, this distinctive architectural feature of Voyvoda is one of the most 
important built element for activity and movement (Figure 11 and Figure 12).

\section{Architectural Features of Buildings}

Although there are reinforced concrete buildings, on both sides of the street, 40 historical buildings reflect the urban development during the last period of the empire and nation (Eldem, 1999). Despite their common architectural qualities - the basic components of physical form and the shared identity of the street - the buildings also exhibit some different architectural expressions (Figure 15 and Figure 16). As Hegemann and Peets (1922, pp 187) point out, 'the street architecture reflects the difficulty of combining the large amount of individuality required by the difference of taste and practical needs of the individual owners with the necessary element of harmony'.

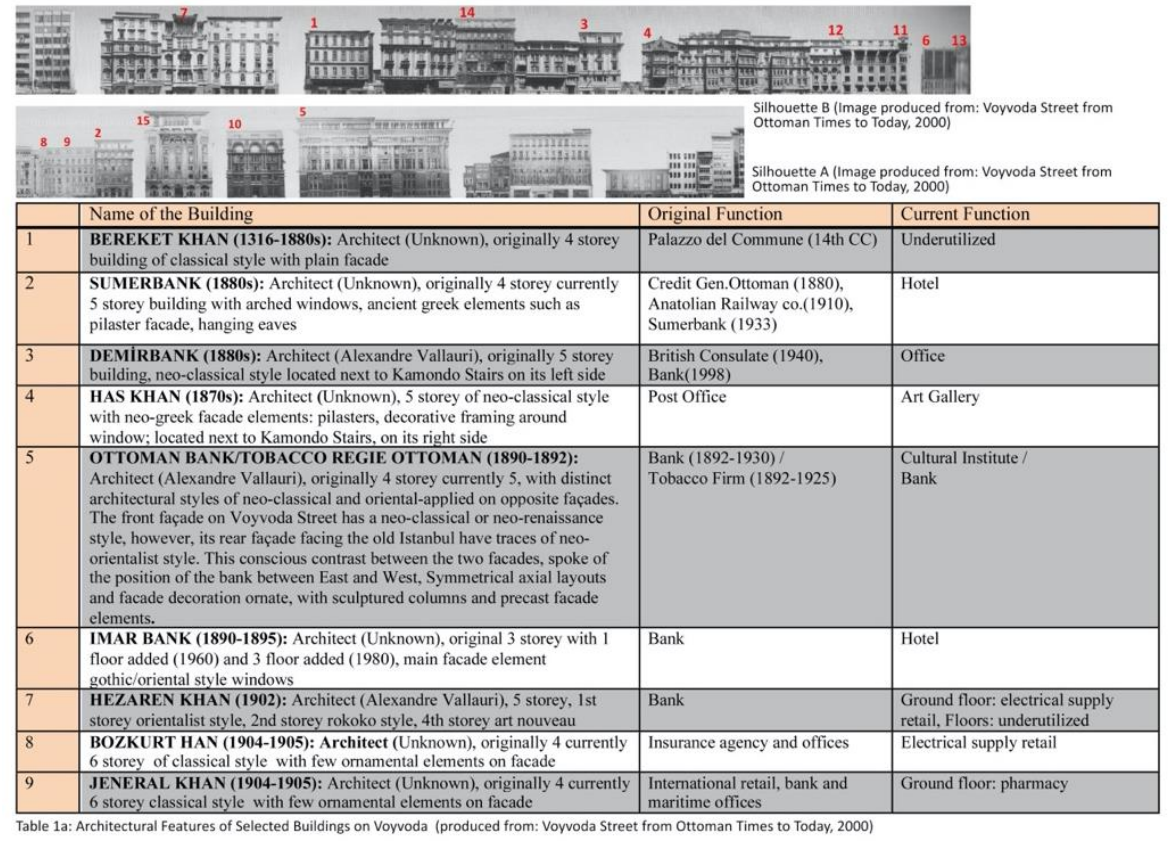

In general, the architectural identity of the street can be described as high-rise masonry buildings with neoclassical facades. In addition to the predominant art nouveau and rococo styles, neo-Greek items are expressed on the building facades as structural and decorative elements. Symmetrical axial layouts were generally preferred in the facades and façade decoration became ornate with sculptured columns and precast facade elements (Kuban, 2016) however most of the buildings are without ornamentation. There are also early examples of the national style containing gothic orientalist items and mosaic ornamentations from the twentieth century (Figure 15 and Figure 16).
Figure 15. Architectural Features of the Buildings (1). 
Figure 16. Architectural Features of the Buildings (2).

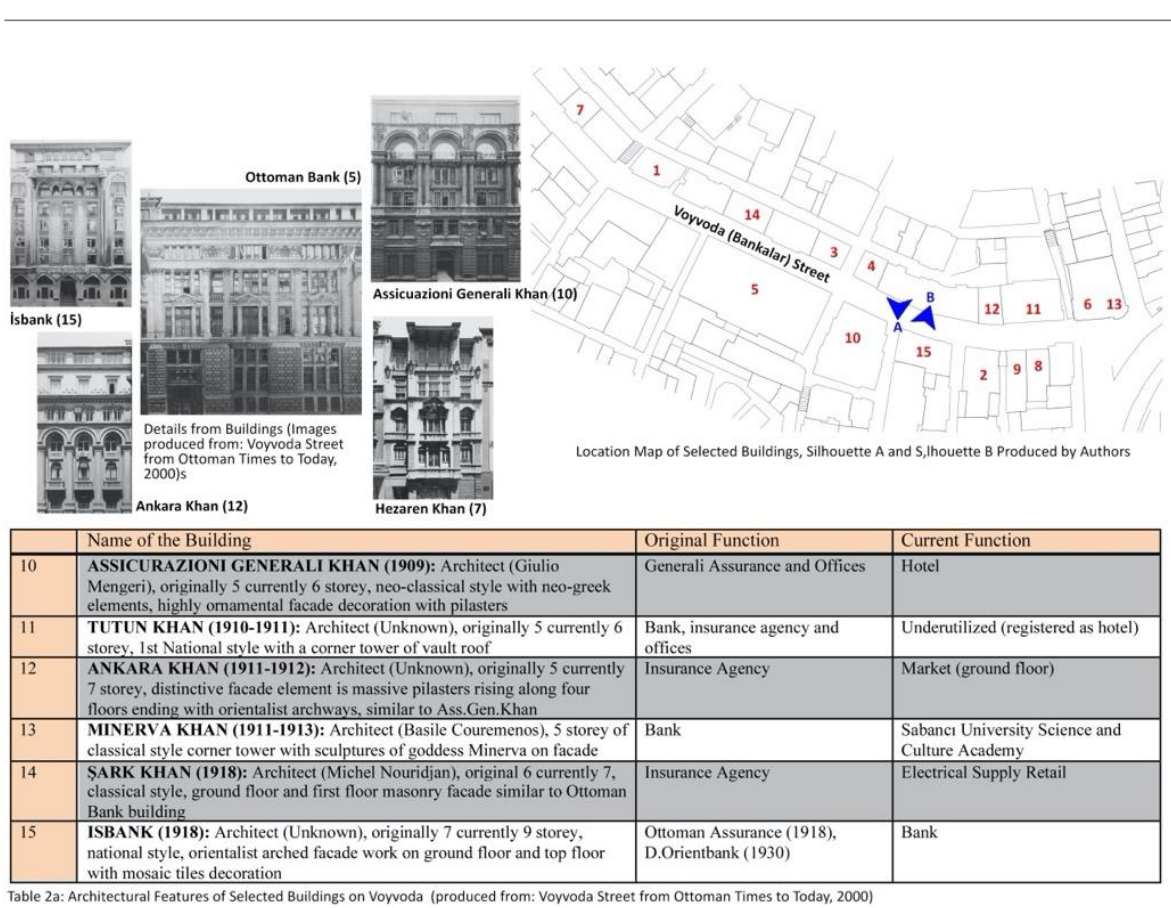

The Ottoman Bank building is one of the most important structures on the Street and has become a focal point. The building has distinctive architectural styles -the front façade on Voyvoda Street has a neoclassical or neo-Renaissance style; however, its rear façade facing the old Istanbul has traces of a neo-Orientalist style. This conscious contrast between the two facades emphasizes the East-West synthesis (Altan, 2007; Alpay, 2007). Another distinctive built element, Kamondo Stairs with its art nouveau style functions as the vertical connection between Galata and Voyvoda and it is one of the most significant features defining the street's identity. In time, the historical characters of some buildings have been changed by new additions, which do not correspond with the original identity of the street. Nevertheless, the number of reinforced concrete buildings has increased in the post-Republic period, the original silhouette of the nineteenth century is still dominant.

\section{DISCUSSION}

Cities grow, transform, and sprawl with economic, social, cultural, technical, and political dynamics. The historical background, urban context, and identical elements identify the character of any place in a city. The conservation of the place identity and changing social and economic needs of the city should be concurrently taken into consideration. Contemporary planning approaches for historical areas are based on the integration of heritage assets within its larger urban setting. The aim of planning should consider the values and identity of historical urban space in a holistic way as part of the living city. The street is one of the main determinants of the urban context, which represents the history of the city as a space where buildings form a character and series of view. 
Voyvoda Street, which is a stunning and unique axis, has retained its distinctive character over centuries and generated its own urban value throughout history. The street has been produced and transformed by social, political, and economic developments, external and internal migrations, the influence of modernist architectural movements, urban reforms, Western innovations in transportation, and technical developments. The built environment of Voyvoda Street, which has significant historical value, reflects the knowledge, construction methods, architectural styles, and traditions of the nineteenth century. The essential urban identity of Voyvoda Street is the axial form and its functional role in history. The buildings on the street are the main physical elements, and together they define a whole image. Furthermore, the street is the essential link binding these buildings socially and economically, since it supports their ability to function together. In brief, the effects of various phenomena throughout history and reflections of milestones are:

- The geographical position in the city and the socio-economic effects of being a port throughout history

- Modernization in the last period of the Ottoman Empire with the adoption of Western approaches to urbanization at the beginning of the nineteenth century

- Transformation of medieval walls into urban streets connecting the whole Galata area to its surroundings

- Capitalist decisions for economic power at the end of the nineteenth century

- Construction of national identity and the financial sector role at the beginning of the twentieth century

- Development of the central business district and its abandonment at the end of the twentieth century

- The dominance of service sector and culture industries since the beginning of the twenty-first century

In the history of the street, the strongest axial character has been produced with the financial function of the banks during the nineteenth century. Later on, by the loss of original functions, the axial character has weakened until the twenty-first century. Following the rise of tourism and cultural industries in the district, the revitalization of the street has been launched during the 2000s. Still, the street is under the influence of new dynamics and is undergoing a process of reconstruction of its identity. It is important to maintain and emphasize the axial character through association with the urban dynamics of the street as a place for urban activities.

Since most of the buildings lost their original functions, following the reuse for various needs, the service and cultural industries have become dominant. For instance, one of the initial examples of the growth of cultural industries on Voyvoda Street is SALT, a public cultural institution that serves as a social gathering space and produces public value for the 
The Urban and Architectural Characteristics of Voyvoda Street from Past to Present

city. However, the re-use process proceeds as a building-based approach in contrast to Voyvoda Street's unity and its centuries-old axial character. So, rather than taking individual structural and functional decisions, it is necessary to evaluate the axis with a street-scale planning approach.

\section{CONFLICT OF INTEREST}

No conflict of interest was declared by the authors.

\section{FINANCIAL DISCLOSURE}

The authors declared that this study has received no financial support.

\section{ETHICS COMMITTEE APPROVAL}

Ethics committee approval was not required for this article.

\section{LEGAL PUBLIC/PRIVATE PERMISSIONS}

In this research, the necessary permissions were obtained from the relevant participants during the site observations.

\section{REFERENCES}

Akin, G. (2011). 20. Yüzyıl Bașında İstanbul: Toplumsal ve Mekansal Farklılaşma, Osmanlı Başkentinden Küreselleșen İstanbul'a: Mimarlık ve Kent 1910-2010. İstanbul, Osmanlı Bankası Arşiv ve Araştırma Merkezi.

Akin, N. (1998). 19. Yüzyılın İkinci Yarısında Galata ve Pera. Literatür Yayıncillk.

Akpınar, İ. (2011). Osmanlı Başkentinden Küreselleşen İstanbul'a: Mimarlık ve Kent 1910-2010. Osmanlı Bankası Arşiv ve Araştırma Merkezi.

Alpay, S. (2007). Voyvoda (Bankalar) Caddesi'nin Tarihsel Gelişimi ve Hezaren Han, Master of Science Thesis, Yildiz Technical University, Institute of Science.

Altan, B. (2007). 'Arşiv Belgeleri Ișığında Hezaren Han'ın Yapısal Çözümlemesi, Master of Science Thesis, Istanbul Technical University, Institute of Science.

Ashworth, G. J. \& Tunbridge, J. E. (1990). The Tourist-Historic City. Belhaven.

Ashworth, G. J. \& Larkham, P. J. (1994). Building a New Heritage: Tourism, Culture and Identity in the New Europe. London, Routledge.

Bandarin, F. and Van Oers, R. (2012). The Historic Urban Landscape. Hoboken Wiley.

Bandarin, F. and Van Oers, R. (2015). Introduction Urban Conservation and the End of Planning, In F, Bandarin, and Oers, V (Eds.). Reconnecting the City. Wiley, UK.

Batur, A. (1996). Dünya Kenti İstanbul. Yapı Kredi Yayınları.

Batur, A. (2001). Galata and Pera, A Short History: Urban Development Architecture and Today. ARI: The Bulletin of the Istanbul Technical University, 55(1), 1-10. 
Bilgin, I. (2010). İstanbul 1910-2010, Kent, Yapılı Çevre ve Mimarlık Sergisi Kataloğu. İstanbul Bilgi Üniversitesi Yayınları.

Bullen, P. A., \&Love, P. E. D. (2010). The rhetoric of adaptive reuse or reality of demolition: Views from the field. Cities, 27, 215-224.

Can, C. (1999). Tanzimat and Architecture. In N.Akın (Eds.) 7 Centuries of Ottoman Architecture: A Supra-National Heritage. İstanbul, Yapı-Endüstri Merkezi Publications.

Carmona, M., Heath, T., Oc, T. and Tiesdell, S. (2003). The Dimensions of Urban Design. In M. Carmona et al. (Eds.) Public Places - Urban Spaces. Oxford, Architectural Press.

Celik, Z. (1998). 19. Yüzyılda Osmanlı Başkenti Değișen Istanbul. Tarih Vakfı Yurt Yayınları.

Dokmeci, V., Altunbas, U., \& Yazgi, B. (2007). Revitalisation of the main street of a distinguished old neighbourhood in Istanbul. European Planning Studies, 15(1), 153-166.

Eldem, E. (1999). Bankalar Caddesi: Osmanlı'dan Günümüze Voyvoda Caddesi. Osmanlı Bankası Arșiv ve Araştırma Merkezi. Tarih Vakfı.

Eldem, E. (2000). İstanbul: İmparatorluk Payitahtından Periferleşmiş bir Başkente. In E. Eldem; D. Goffman; B. Masters; translation S. Yalçın. Doğu ve Batı kenti arasında Osmanlı Kenti: Halep, İzmir, Ístanbul. İstanbul, Tarih Vakfı Yayınları.

Eroğlu, Ö. (1992). Sur İçi Galata'sı Üzerine Bir Deneme, Istanbul Üniversitesi Sosyal Bilimler Enstitüsü Yüksek Lisans Tezi.

Eyice, S. (1996). Galata Kulesi, Türkiye Diyanet Vakfı İslam Araştırmaları Merkezi, İslam Ansiklopedisi, (13), 313-316.

García-Hernández M, De la Calle-Vaquero M, Yubero C. (2017). Cultural Heritage and Urban Tourism: Historic City Centres under Pressure. Sustainability, 9(8), 13-46.

Gençer, C. İ., Çokuğraş, I, (2016). Osmanlı İmparatorluğu'nda Kentsel Mekânın Düzenlenmesi: İstanbul Örneği (1820-1900). Megaron, 11(1), 1-14.

Gibberd, F. (1955). Town Design. Architectural Press.

Gospodini, A. (2004). Urban Morphology and Place Identity in European Cities: Built Heritage and Innovative Design. Journal of Urban Design, 9(2), 225-248.

Gutman, R. (1986). The Street Generation. In S. Anderson (Eds.). On Streets. MIT Press, Cambridge, Mass.

Güvenç, M., et al., (2012). Azman Sanayi Kentinden Kentsel Bölgeye. In İstanbul 1910-2010, Kent, Yapılı Çevre ve Mimarlık Sergisi Kataloğu. İstanbul Bilgi Üniversitesi.

Hansen, H. (2012, February 12). The Istanbul Art-Boom Bubble. The New York Times Magazine, Retrieved from URL www.nytimes.com.

Hartshorn, T.A. (1992). Interpreting the City. Canada, Jon Wiley and Sons. Harvey, D. (2008). The Right to the City. New Left Review, 53, 23-40. 
The Urban and Architectural Characteristics of Voyvoda Street from Past to Present

Hegemann, W. \& Peets, E. (1922). The American Vitrivius, An Architect's Handbook of Civic Art. Benjamin Blom.

Hosagrahar, J. (2015). Knowledge and Planning Tools. In F. Bandarin and O. Van (Eds.). Reconnecting the City. Wiley, UK.

Kostof, S. (1992). The City Assembled. Bullfinch Press.

Kuban, D. (1998). Kent ve Mimarlı Üzerine İstanbul Yazıları. Yem Yayınları.

Kuban, D. (2016). Osmanlı Mimarisi. Yem Yayınları.

Larkham, P. \& Jones, A. (1993). The character of conservation areas in Great Britain. Town Planning Review, 64(4), 395-413.

Lowenthal, D., \&Binney, D. (1981). Caring for the past: Changing attitudes. In D. Lowenthal \& D. Binney (Eds.). Our past before us: Why do we save it? London, Temple Smith.

Lynch, K (1960). The Image of the City. MIT Press.

Mehta, V. (2013). The Street: A Quintessential Social Public Space. Routledge. ISBN: 0415527104, 9780415527101.

Moudon, A.V. (1991). Public Streets for Public Use. Columbia University Press. ISBN: 0231075995, 9780231075992.

Moughtin, C. (2003). Urban Design: Street and Square. Architectural Press. Norberg-Schulz, C. (1971). Existence, Space and Architecture. Cox and Wyman.

Norberg-Schulz, C. (1980). Genius Loci: Towards a Phenomenology of Architecture. Academy Editions.

Ortayli, I. (2016). Eski Beyoğlu'ndan Çizgiler. İnkılap Kitabevi.

Özbay, C., Candan, B. A., (2014). Sunuș, In C. Özbay and B. A. Candan Yeni İstanbul Çalışmaları. İstanbul, Metis Yayıncılık.

Plevoets, B., \& Van Cleempoel, K. (2013). Adaptive reuse as an emerging discipline: An historic survey. In G. Carns (Eds.) Reinventing architecture and interiors: a socio-political view on building adaptation, London, Libri Publishers.

Powell, K. (1999). Architecture reborn. Converting old buildings for new uses. Rizzoli International Publications.

Rapoport, A. (1987) Pedestrian Street Use: Culture and Perception. In A. V. Moudon (Eds.) Public Streets for Public Uses. Portland, VNR.

Relph, E. (1976). Place and Placelessness. Pion.

Schumacher, T. (1986) Buildings and streets. In S. Anderson (Eds.) On Streets (pp.132-149). MIT Press, Cambridge, Mass.

Scott, F. (2008). On altering architecture. Routledge.

Smithson, A. and Smithson, P. (1967). Urban Structuring. Studio Vista.

Steele, F. (1981). The Sense of Place. Boston, CBI.

Tunbridge, J. E. \& Ashworth, G. J. (1996). Dissonant Heritage: The Management of the Past as a Resource in Conflict. Chichester, Wiley. 
Zukin, S. (2012). The social production of urban cultural heritage: Identity and ecosystem on an Amsterdam shopping Street, City. Culture and Society, 3, 281-291.

\section{Resume}

Serengül Seçmen currently works at Bahçeşehir University, Department of Architecture as an Assistant Prof. Dr. since 2019. She received her Urban Design Master degree from Mimar Sinan Fine Arts University in 2005. After working professionally on several architectural projects, she got her PhD from the City and Regional Planning Department of Istanbul Technical University in 2019.

Elif Süyük Makaklı currently works at Işıl University, Department of Architecture, as an Associate Prof. She received her Ph.D. at Vienna University of Technology Faculty of Architecture. She worked as an architect in different offices and firms in Istanbul and Vienna. She is conducting research activities in the areas of architectural design, traditional architecture, technology and architecture. 